\title{
THE PROPHETIC VOICE OF AMOS AS A PARADIGM FOR CHRISTIANS IN THE PUBLIC SQUARE
}

\author{
Gerald A. Klingbeil and Martin G. Klingbeil
}

\begin{abstract}
Summary
This study focuses upon the OT prophet Amos and his life, mission, and message in the context of Christians in the public square. After a brief introduction to the concept of the public square, the study introduces important biographical, geographical and historical facts that are relevant in order to understand Amos' prophetic voice in the public square. Amos' message is clearly an international message (Amos 1-2) and a message critical to religious traditions and structures that are disconnected from practical ethical living (Amos 5:21-27). The judgement motif is another relevant topic of Amos' public discourse (Amos 7-9) and while not a popular theme in current discourse needs to be taken into consideration if one would like to learn from Amos' prophetic voice. Finally, Amos exits his public square experience with a word of hope, reminding us that judgement and hope are highly interconnected themes which need to be presented concurrently.
\end{abstract}

\section{Introduction or What We Actually Mean by the Public Square}

The concept of the public square is indeed an old one. Most ancient cultures boasted a public place where the citizens (and others) of the community interacted. ${ }^{1}$ In Spanish-speaking countries each town had a plaza. In ancient Israel the gate area was the public place where

1 In Greek culture this place was known as the agora, or central marketplace which played a major role in any Greek polis. During the Roman period this public space is known as the forum (Forum Romanum or Forum Magnum). 
business, law cases, and other important public issues were handled. ${ }^{2}$ Over the past decades it has become a catchword of modern society. Thought leaders, interest groups, governments, and also religious denominations claim a stake in the public life of a city, country, and, increasingly, the world (or was that the internet?). Statements made by a religious, political, or business leader in Rome, Jakarta, or Seattle appear on the newsticker of international news outlets in minutes and are read and interacted with in public forums, blogspots, e-publications, or e-mails to the news outlet. ${ }^{3}$

The public square is the place where opinions are formed and thoughts are exchanged and it is here that Christianity wants to be

2 The importance of gates for ancient communities has been discussed in research dealing with the material culture of the ANE. Compare here, for example, most recently A, A. Burke, 'The Architecture of Defense: Fortified Settlements of the Levant during the Middle Bronze Age' (Ph.D. dissertation, Oriental Institute of the University of Chicago, 2004): 133-53, who deals with gates as part of a larger defence system during MBA. Earlier compare also A. Kempinski, 'Middle and Late Bronze Age Fortifications' in The Architecture of Ancient Israel: From the Prehistoric to the Persian Period, ed. A. Kempinski and R. Reich (Jerusalem: Israel Exploration Society, 1992): 127-42, and Z. Herzog, 'Middle and Late Bronze Age Fortifications' in The Architecture of Ancient Israel ed. Kempinski and Reich, 231-74, esp. 271-74. A helpful discussion of the gate (as part of the larger fortification system) during the Persian period in Palestine can be found in J. W. Wright, 'A Tale of Three Cities: Urban Gates, Squares and Power in Iron Age II, Neo-Babylonian and Achaemenid Judah' in Second Temple Studies III: Studies in Politics, Class and Material Culture, ed. P. R. Davies and J. M. Halligan (JSOTSup 340; Sheffield: Sheffield Academic Press, 2002): 19-50. Gates in Palestine also played a major influence in the religious life of a city and marked important liminal space. See here the important works of Tina Haettner Blomquist, Gates and Gods: Cults in the City Gates of Iron Age Palestine: An Investigation of the Archaeological and Biblical Sources (Coniectanea Biblica. Old Testament Series 46; Stockholm: Almqvist \& Wiksell, 1999); M. Bernett and O. Keel, Mond, Stier und Kult am Stadtor: Die Stele von Betsaida (et-Tell) (OBO 161; Fribourg: Universitätsverlag; Göttingen: Vandenhoeck \& Ruprecht, 1998); and J. A. Emerton, "“The High Places of the Gates" in 2 Kings xxiii 8', VT 44 (1994): 455-67. A general introduction to the city in ancient Palestine can be found in V. Fritz, Die Stadt im alten Israel (Beck's Archäologische Bibliothek; München: Verlag C. H. Beck, 1990). Some of the relevant biblical data pertaining to the gate includes Gen. 19:1 [Lot welcomes the visiting angels in the city gate]; 34:20 [Hamor and his son speak to the men of his city at the gate]; Deut. 22:15 [parents demonstrate the sexual purity of their daughter at the gate]; 22:24 [adulterers are stoned at the gate]; $25: 7$ [issues concerning the Levirate marriage are sorted out at the gate]; Ruth 4:1 [Boaz negotiates publicly with the next-of-kin at the gate], etc.

3 A quick search on www.google.com for 'public square' produced an impressive list of websites dedicated to reflect, interact with, and mould public opinion, ranging from Catholic [http://thepublicsquare.blogspot.com], or Protestant [http://www.christian cadre.org/public_square.html] concerns via scientific research groups [http://www. thepublicsquare.org] to local or regional radio programmes with different agendas [http://www.ohioroundtable.org/tps/index.cfm]. 
present. ${ }^{4}$ After all, a good NT paradigm for Christian public interaction can be found in Paul's visit to the óropó 'marketplace' of Athens (Acts 17:17-18), which shows a Paul freely interacting with distinct ethnic and religious groups. ${ }^{5}$

In this paper we will try to look at the public square concept from the perspective of the Hebrew Bible. This may be a challenging enterprise, considering the fact that most missiologists in the past have overlooked (or at least ignored) the missiological data found in it, due to the presupposition that Israel's mode of mission was centripetal in nature (i.e. inward moving, requiring people to come to Jerusalem and making people passive participants in the fulfillment of the mission). ${ }^{6}$ On the other side of this spectrum, most missiologists saw the basic NT orientation of missions as centrifugal (i.e. outward moving, requiring

4 During the research for this paper it has been surprising to us to see the huge numbers of Christian websites that are aiming at the public space of the internet hypersociety. A quick sampling of recent academic publications on the subject shows a wide variety of approaches and perspectives, most of which are not reflective about the biblical foundation for Christians in the public square (which is generally taken for granted), but rather focus upon the mode(s) of interaction. See here, for example, D. L. Adams, 'The Church in the Public Square in a Pluralistic Society', Concordia Journal 28 (2002): 364-90, who looks at the junction of Christians, the public square and pluralism and seeks to define 'American Civil Religion'. The challenging study of J. O'Connor, 'Fostering Forgiveness in the Public Square: How Realistic a Goal?', Journal of the Society of Christian Ethics 22 (2002): 165-82, focuses upon the seldom practised and difficult to implement concept of forgiveness in the public square, based upon the experience of post-Apartheid South Africa. R. Lee, 'The Force of Religion in the Public Square', Journal of Communication and Religion 25 (2002): 6-20, has correctly observed the presence and function of religion in the public square - even from secular participants of the public debate. An interesting contribution was made by D. McLellan, 'Making Connections: Faith in the Public Square', Theological Education 38 (2001): 61-72, who ponders the role of religious education at Washington Theological Union and its proximity to the power centre of the USA. This list could be added on indefinitely.

5 This interpretation can be found, for example, in D. Flemming, 'Contextualizing the Gospel in Athens: Paul's Areopagus Address as a Paradigm for Missionary Communication', Journal of Religious and Theological Information 4 (2001): 199-214, and earlier J. Q. von Ehrenkrook, 'A Rhetorical Analysis of the Areopagus Speech and Its Missiological Implications', Calvary Baptist Theological Journal 14.2 (1998): 1-15, and J. D. Charles, 'Engaging the (Neo)Pagan Mind: Paul's Encounter with Athenian Culture as a Model for Cultural Apologetics (Acts 17:16-34)', TrinJ 16 (1995): 47-62, who both argue along similar lines.

6 See R. W. Medina, 'La estructura de la misión de Moisés a los egipcios en la narrativa del éxodo: algunas implicancias para la misión de la iglesia' (Lic. thesis; Universidad Adventista del Plata, 2005): 1-6. 
the early church to actively move out in order to reach out to the world). ${ }^{7}$

Obviously, due to time and space limitations of this paper, it is not possible to deal adequately with all the relevant data. For this reason we have decided to limit ourselves and look at the prophet Amos as a helpful paradigm for Christians in the public square. The first section will include a concise introduction to Amos the man, his particular historical context and mission and his message. This is followed by four sections that focus on four distinct characteristics of Amos' message. First, we will look at his oracles against the nations (Amos 12) and their international perspective. Second, Amos' critique of the ritual practice of his contemporaries will be dealt with in an attempt to understand why the prophet spoke so critically about established cult practice and important religious forms. Third, we will turn to Amos' theology of judgement and its relevance in the public square, which will be followed by a discussion of his message of hope. In our concluding remarks we will try to develop a set of Scripture based characteristics of the Christian message (and witness, thus recognising the missiological dimension of the enterprise) in the public square that take as their model the ministry and message of the prophet Amos.

\section{Amos: The Man and His Mission}

The historical framing of the book of Amos in 1:1 provides some helpful information about the man and his mission. Amos is associated with the small town of Tekoa, a village some ten kilometres south of Bethlehem and eighteen kilometres south of Jerusalem. ${ }^{8}$ The

7 This dilemma has recently been described in the important volume by W. C. Kaiser, Jr, Mission in the Old Testament: Israel as a Light to the Nations (Grand Rapids: Baker, 2000): 9-10, who seeks to provide a more balanced perspective towards the issue.

8 Helpful introductions to the book of Amos, including discussions of the man and his mission, can be found in G. V. Smith, Amos: A Commentary (Grand Rapids: Zondervan, 1989): 1-4; F. I. Andersen and D. N. Freedman, Amos: A New Translation with Introduction and Commentary (AB 24A; New York: Doubleday, 1989): 18-23, 83-88; S. M. Paul, Amos (Hermeneia; Minneapolis: Fortress, 1991): 1-7, 33-36; J. Niehaus, 'Amos' in The Minor Prophets: An Exegetical \& Expository Commentary, ed. T. E. McComiskey (3 vols.; Grand Rapids: Baker, 1992): 1:315-17; B. K. Smith and F. S. Page, Amos, Obadiah, Jonah (NAC 19B; Nashville: Broadman \& Holman, 1995): 23-28; J. Jeremias, The Book of Amos (OTL; Louisville: Westminster John Knox, 1998; tr. D. W. Stott): 1-2. 
introductory verse includes a typical synchronistic dating, referring to Uzziah, king of Judah, and Jeroboam II, king of Israel, which situates his ministry during the first half of the eighth century B.C.E., more

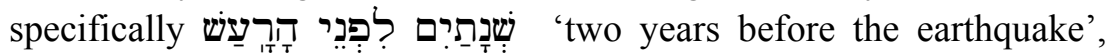
which has been archaeologically dated to around 760 B.C.E. ${ }^{9}$ Amos is described as belonging to the נָקְִדים 'sheepbreeders' of Tekoa which needs to be distinguished from the regular רצעד 'shepherd'. In Akkadian texts the re' $\hat{u}$ 'shepherd' is subordinate to a nāqidu who in a Neo-Babylonian text is described as a second-level official associated with a temple. ${ }^{10}$ The close link to Tekoa (instead of Jerusalem) in the opening lines of Amos would suggest that the Hebrew נפקְדרים is not associated with the temple of Jerusalem, particularly in view of the fact that, distinct from Mesopotamian or Egyptian temples, we do not know of any temple herds and shepherds in Israelite religion. ${ }^{11}$ In conjunction

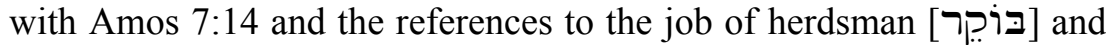

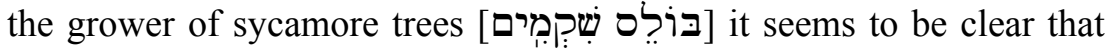
the prophet was not a simple farmhand or shepherd, but most probably a well-to-do Judahite who held a managerial position in the local sheep industry. The choice of terminology here also indicates that Amos was a public person in his community and beyond. ${ }^{12}$

9 See here, for example, Paul, Amos, 35; or Niehaus, 'Amos' in The Minor Prophets, 1:317. For further discussion of the archaeological evidence of eighth century B.C.E. earthquakes in Palestine see William G. Dever, 'A Case-Study in Biblical Archaeology: The Earthquake of 760 B.C.E.' in Avraham Biran Volume, ed. Ephraim Stern and Thomas E. Levy (Eretz Israel 23; Jerusalem: Israel Exploration Society/Hebrew Union College, 1992): $27^{*}-35^{*}$. Compare also the discussion of the correlation of archaeological data with biblical data, particularly the references found in Amos, in Michael G. Hasel, 'New Early Eighth Century B.C. Earthquake Evidence at Tel Gezer: Archaeological, Geological, and Literary Indications and Correlations' (M.A. thesis, Andrews University, Theological Seminary, 1992): 40-82.

10 M. San Nicolò, 'Materialien zur Viehwirtschaft in den neubabylonischen Tempeln. I', Orientalia 17 (1948): 284-85. Compare also Shalom, Amos, 34, esp. the references in n. 18.

11 Gerhard F. Hasel, Understanding the Book of Amos: Basic Issues in Current Interpretations (Grand Rapids: Baker, 1991): 36-37. Furthermore, note the data from 2 Kgs 3:4 where King Mesha of Moab is reported to be a נקר who used to pay as tribute to the kings of Israel [the wool of] 'a hundred thousand lambs and the wool of a hundred thousand rams'. Some scholars reconstruct lines 30-31 in the famous Mesha stele as ואיא שם את נ[קדי לרעת את] 'I led [my shepherds] up there [in order to tend the] sheep of the district.' Compare here J. C. L. Gibson, Textbook of Syrian Semitic Inscriptions: Vol. I. Hebrew and Moabite Inscriptions (Oxford: Clarendon Press, 1971): 74-75, 82.

12 Cf. Peter C. Craigie, 'Amos the noqed in the light of Ugaritic', Studies in Religion/Sciences religieuses 11.1 (1982): 29-33. 
The initial verse of the book of Amos also points to the location of

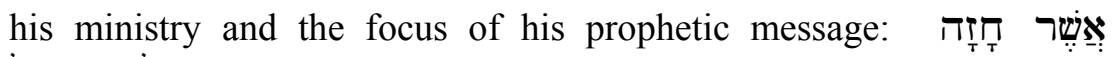

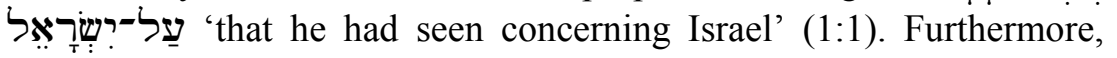
many of his messages are connected to Israel ${ }^{13}$ and there is a historic narrative in Amos 7:10-17 that is sandwiched between prophetic oracles and provides a backdrop for the ministry of Amos. The two protagonists of this narrative involve Amos himself and Amaziah, the priest of Bethel (7:10) who sends a message to Jeroboam II, king of Israel, complaining about the prophetic ministry of Amos in that particular location.

In this encounter Amos employs a phrase that provides additional

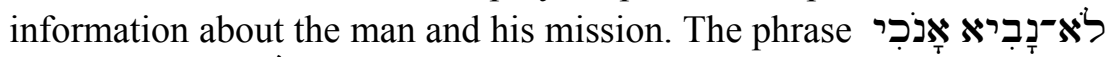
I 'I was [am] no prophet and I was [am] also not a son of a prophet' (7:14) has been interpreted as an indication of the distinct nature of Amos' prophetic ministry. Many commentators have spent considerable effort determining the exact meaning of these short parallel nominal clauses and this is not the time and place to rehash their efforts. ${ }^{14}$ What appears to be clear, however, is that the prophet does not claim to have received particular training for his prophetic ministry as can be noted in the particular reference to his prior occupation in agriculture. Amos was an outsider, both politically, as well as professionally and did not receive training (nor accreditation) from the guild of prophets. ${ }^{15}$ But due to divine calling, a trait shared with other classical prophets of the Hebrew Bible (1 Kgs 19:19-21; Isa. 6:1-13; Jer. 1:4-10; Ezek. 2:1-7), Amos claims to do what true prophets do, they נבץ 'prophesy', i.e. speak in the name of YHWH. It should be noted that this divine calling to speak YHWH's word into a specific time, place, and context seems to overrule Amaziah's charge and warning (7:10-13). It drives the prophet to leave his business (or

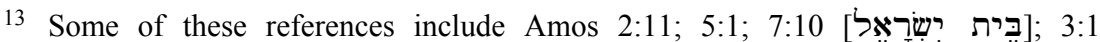

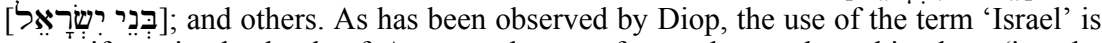
not uniform in the book of Amos and can refer to the northern kingdom (i.e. the historic Israel), the united kingdom, both the northern and southern kingdoms and a future Israel. For more details see A. Ganoune Diop, "The Name "Israel" and Related Expressions in the Books of Amos and Hosea' (Ph.D. dissertation, Andrews University, Theological Seminary, 1995): 224-26.

14 See here the references in Hasel, Understanding the Book of Amos, 41-47; and Paul, Amos, 244-48.

15 The biblical references which indicate the sharing in a particular quality or group that Paul, Amos, 244, has supplied are sufficient and need not be repeated here.
} 
occupation), his tribal unit, ${ }^{16}$ the familiar home surroundings and travel to neighbouring Israel which in the past has often been hostile to the southern kingdom of Judah. Somehow, this underlying hostility can be felt in Amaziah's charge against Amos (7:13) who has spoken out at

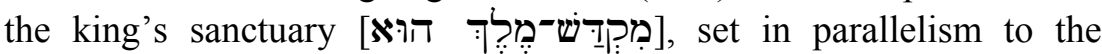

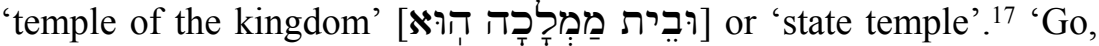

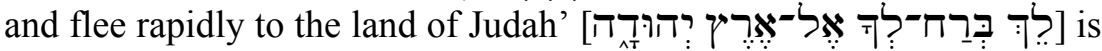
Amaziah's advice (7:12) to Amos, followed up by the suggestion to

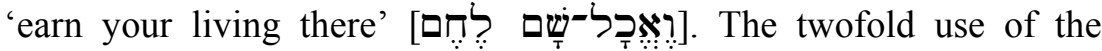
adverb $\underset{\sim}{\mathbb{*}}$ 'there' suggests that 'here' (i.e. in Israel) would not be a good place to remain, an idea already introduced in 7:10 in the letter

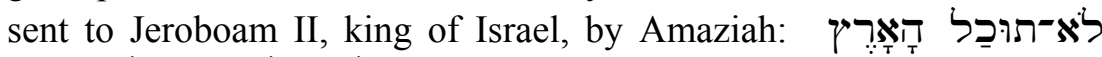

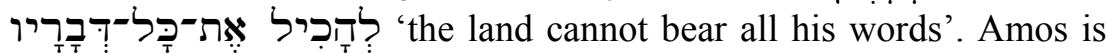
portrayed both as an intruder and foreigner whose message is not appreciated and who does not have the right certification. Truly, these are not first-class credentials for someone speaking in the public square!

\section{Amos 1-2: An International Message}

As already noted above, biblical scholars have traditionally described the missiological perspective of the Hebrew Bible as basically centripetal. ${ }^{18}$ However, beginning in the 1950 s and due to increased interaction of biblical scholars with missiologists, models stressing a

\footnotetext{
16 We are using the term 'tribal unit' as referring to a closely knit kinship group. The western notion of a 'nation' or a 'state' (as an integrated and highly complex entity) is not at all present in the ancient Near East. One should rather consider these divisions in terms of distinct tribal groups. For a good discussion of the relationship between the concepts of 'nation/state' and 'tribe' see the doctoral dissertation of Zeljko Gregor, 'Sociopolitical Structures of Transjordanian Societies during the Late Bronze and Iron I Ages (ca. 1550-1000 B.C.)' (Ph.D. dissertation, Andrews University, Theological Seminary, 1996): 127-72, esp. 154-61. Compare also the application of the tribal model to Transjordanian LBA society in Øystein Stan LaBianca and Randy W. Younker, 'The Kingdoms of Ammon, Moab and Edom: the Archaeology of Society in Late Bronze/Iron Age Transjordan (ca. 1400-500 BC)' in The Archaeology of Society in the Holy Land, ed. Thomas E. Levy (London: Leicester University Press, 1998): 399-415.

17 This translation has been taken from Paul, Amos, 238.

18 This trend has also been noted recently in Sung Ik Kim, 'Proclamation in CrossCultural Context: Missiological Implications of the Book of Daniel' (Ph.D dissertation, Andrews University, Theological Seminary, 2005): 1-2, and extensive bibliographical references given there. Compare also Kaiser, Mission in the Old Testament, 7-10.
} 
more centrifugal perspective of mission have been promulgated. ${ }^{19}$ Obviously, this issue affects our present concern. If the prophets of the Hebrew Bible wrote not only addressing the issues and problems of YHWH's chosen people Israel, but demonstrate a wider perspective, they would be standing in an international forum, pointing to the larger public square of the world which goes beyond national borders and local or regional interests.

The prophetic message of Amos definitely would fit this bill. The section of Amos 1:3-2:16 includes oracles dealing with eight different people groups, beginning with the foreign (and mostly hostile) 'nations' of Aram (Damascus), Philistia (Gaza), and Phoenicia (Tyre), which are followed by peoples that are somewhat related, including Edom, Ammon, and Moab. Finally, the sister nation of Judah is mentioned, followed by a devastating blow against the northern kingdom of Israel itself. ${ }^{20}$ The first seven oracles are very uniformly structured, ${ }^{21}$ while the eighth about Israel displays a different structure, thus heightening the rhetoric effect directed towards the audience, hailing from the northern kingdom of Israel. ${ }^{22}$ According to Paul Raabe more than ten percent of the book of Amos is dedicated to the oracles

19 Kim, 'Proclamation in Cross-Cultural Context', 2-7, and the bibliographic references provided there. Compare also the relevant study of Medina who studied the Exodus plague narrative in terms of its missiological dimensions (Medina, 'La estructura de la misión de Moisés a los egipcios en la narrativa del Éxodo').

20 The literature about these oracles against the nations is quite extensive. Apart from the standard commentaries reference should be made to the following (from more recent to earlier studies), Andreas Scherer, 'Vom Sinn prophetischer Gerichtsverkündigung bei Amos und Hosea', Biblica 86 (2005): 1-19; Pierre Berthoud, 'The Covenant and the Social Message of Amos', European Journal of Theology 14 (2005): 99-109; Karl Möller, "Hear This Word Against You": A Fresh Look at the Arrangement and the Rhetorical Strategy of the Book of Amos', VT 50 (2000): 499518; M. Daniel Carroll R., 'God and His People in the Nations' History: A Contextualised Reading of Amos 1-2', TynBul 47 (1996): 39-70; Paul R. Raabe, 'Why Prophetic Oracles Against the Nations?' in Fortunate the Eyes That See: Essays in Honor of David Noel Freedman in Celebration of His Seventieth Birthday, ed. Astrid B. Beck et al. (Grand Rapids: Eerdmans, 1995): 236-57; Anthony R. Ceresko, 'Janus Parallelism in Amos's 'Oracles against the Nations' (Amos 1:3-2:16)', JBL 113 (1994): 485-90.

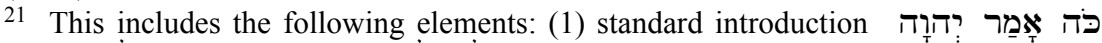

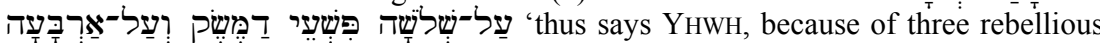
acts of Damascus and because of four' $(1: 3,6,9,11,13 ; 2: 1,4,6) ;(2)$ graded numerical sequence $(\mathrm{x} / \mathrm{x}+1)$; (3) the declaration of the specific rebellion or sin, introduced by the pronoun; (4) עַ the standard pronouncement of judgement involving

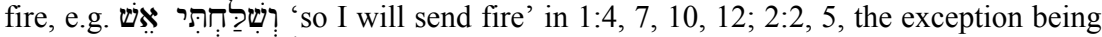

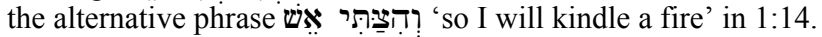

22 See on this for more details Smith, Amos, 70-76, and also Paul, Amos, 76-77. 
against the nations and thus have an international dimension, ${ }^{23}$ a tendency which is also visible in other prophetic books of the Hebrew Bible. While the literary and rhetorical function of Amos' oracles against the nations is important and should be noted, ${ }^{24}$ their inclusion in the canonical book was not only a strategy of more effective or surprising communication to the northern kingdom of Israel. Rather, it seems to have been part and parcel of a larger issue, i.e. the broader (and often inclusive) vision of Israelite's prophets who spoke out on international issues. This tendency becomes even more relevant when one considers the existence of these types of message in most of the oracles of the writing prophets of the eighth-sixth century B.C.E. ${ }^{25}$ Clearly, these must have been more than mere rhetorical devices, and point to the important notion of a universal covenant that includes all inhabitants of the earth. ${ }^{26}$ This covenant with humanity is initiated by God after the flood (Gen. 9) and involves certain principles of rightful

23 Raabe, 'Why Prophetic Oracles Against the Nations?' in Fortunate the Eyes, 237, provides a useful table tabulating the percentage of the oracles against the nations (OAN) in the prophetic texts of the Hebrew Bible. Out of the 2,047 words of the book of $A \operatorname{mos} 214(=10.5 \%)$ are dedicated to the OAN. Isaiah has a ratio of $14.2 \%$, Jeremiah $14.9 \%$, Ezekiel 15\%, etc. Over the past year, much research has been done concerning the reason of the OAN in the prophetic literature, for example, John N. Oswalt, 'The Nations in Isaiah: Friend or Foe; Servant or Partner', Bulletin for Biblical Research 16 (2006): 41-51; J. Severino Croatto, 'The 'Nations' in the Salvific Oracles of Isaiah', VT 55 (2005): 143-61; Menahem Haran, 'The Place of the Prophecies against the Nations in the Book of Jeremiah' in Emanuel: Studies in Hebrew Bible, Septuagint and Dead Sea Scrolls in Honor of Emanuel Tov, ed. Shalom M. Paul et al. (VTSup 94; Leiden: Brill, 2003): 699-706; Karl Möller, 'Words of (In-)evitable Certitude? Reflections on the Interpretation of Prophetic Oracles of Judgment' in After Pentecost: Language and Biblical Interpretation, ed. Craig G. Bartholomew, Colin J. D. Greene and Karl Möller (The Scripture and Hermeneutics Series 2; Grand Rapids: Zondervan; Carlisle, UK: Paternoster, 2001): 352-86.

24 See, for example, the recent works of Möller, "Hear This Word Against You", 499-518, and Paul R. Noble, 'The Literary Structure of Amos: A Thematic Analysis', JBL 114 (1995): 209-26. Compare also the extensive citations provided in M. Daniel Carroll R., Amos-The Prophet and His Oracles: Research on the Book of Amos (Louisville: Westminster John Knox, 2002): 131-34.

25 Based on word count and ratios between book length and the length of the OANs Raabe, 'Why Prophetic Oracles against the Nations?' in Fortunate the Eyes, 237, suggests that $13.6 \%$ of these books included messages to people outside of Israel/Judah. This is, however, a very conservative figure that does not include all relevant texts which pronounce doom against foreign nations (such as Isa. 34; Ezek. 38-39; Joel 4 [ET 3], etc.; Raabe, 'Why Prophetic Oracles against the Nations?' in Fortunate the Eyes, 236).

26 For the important study concerning the presence of covenant terminology and theology in these chapters see Reinaldo W. Siqueira, 'The Presence of the Covenant Motif in Amos 1:2-2:16' (Ph.D. dissertation, Andrews University, Theological Seminary, 1996): 152-281. 
living which the creator God requires of his creation. In other words, the oracles against the nations remind us of universal justice and social responsibility that created beings owe the creator. ${ }^{27}$ In biblical thinking Israel is often described as YHWH's (firstborn) son (Exod. 4:22; Deut. $14: 1 ; 32: 5,19$; Isa. $1: 2 ; 43: 6 ; 45: 11 ; 63: 8$; Jer. $3: 14$, 19, 22; Hos. 2:1; $11: 1),{ }^{28}$ which by extension suggests that there are other 'sons', some of whom have already appeared in the table of nations in Genesis 10:132. It seems as if the prophets understood this universal aspect of sonship and thus included messages to the wayward sons of YHWH in their messages to Israel and/or Judah. ${ }^{29}$ It is true that most of these oracles involved judgement. However, as can also be seen in other classical prophets, salvation also often includes the nations or individual members of the nations together with the covenant people as will be seen in the final message of hope. ${ }^{30}$

What can be learned from this facet of Amos' ministry in Israel that may be relevant for our present question of the Christian in the public square? First, the public square is not only a national or local space (though that is undoubtedly important), but its scope is international. This is due to the interconnectedness of human beings and particularly God's creation. Similar to YHWH's concern in the time of the prophets, the nations, people, and tribes of this planet are indeed part and parcel of God's creation and must be addressed in the public square. Second, it should be noted that Amos' judgement message to most nations

27 This accountability of the nations (and particularly, God's special people Israel and Judah) has also been noted by Berthoud, 'The Covenant and the Social Message of Amos', 99-109.

28 Note here Merling Alomía, 'El motivo del בָּכוֹ en el libro de Éxodo' in Inicios, fundamentos y paradigmas: estudios teológicos y exegéticos en el Pentateuco, ed. Gerald A. Klingbeil (Serie monográfica de estudios bíblicos y teológicos de la Universidad Adventista del Plata 1; Libertador San Martín: Editorial Universidad Adventista del Plata, 2004): 191-227.

29 This is not to say that they were always willing messengers. Jonah's example clearly illustrates some of the national pride and (often justified) hatred that Israelites or Judahites must have felt against their Assyrian (or later Babylonian) overlords or Aramean foes. An illustrative description of the brutal conquest and destruction of Lachish from an archaeological perspective can be found in David Ussishkin, 'The Assyrian Attack on Lachish: The Archaeological Evidence from the Southwest Corner of the Site', Tel Aviv 17 (1990): 53-86.

30 See Croatto, 'The "Nations" in the Salvific Oracles of Isaiah', 143-61, who unfortunately deconstructs these references in Isaiah in terms of the liberation of Diaspora Israelites/Judahites and their future return to Palestine. Suffice it to say that Croatto's conclusions are at least partially determined by his presuppositions, i.e. the date of the particular sections of Isaiah as well as his particular fascination with liberation as one of the (if not the) most important themes of classical prophecy. 
involved social injustice or physical or moral atrocities. In turn a Christian in the public square, parallel to the prophetic voice of the eighth century B.C.E., should raise the voice to defend the powerless, the downtrodden, the abused, the voiceless, and the ones without rights. Spiritual as well as physical and social issues are to be included in this speaking in the public square, against the backdrop of YHWH's covenant with his creation. Third, there is a universal claim that YHWH lays on all nations based on a set of divine criteria that is applicable to both Christians and non-Christians and which should regulate human relationships. Furthermore, the notion of the superiority of one nation or ethnic group over against another must be questioned against this backdrop.

\section{Amos 5:21-27: The Tension between 'Yours' and 'Mine'}

As we have already observed in our comments about the Oracles against the Nations (OAN) Amos does not mince words when it comes to pointing out social and religious flaws in YHWH's covenant people. ${ }^{31}$ One particular point on his agenda involves the nexus between religious activities and practical and ethical daily living, which is also a highly relevant topic for the twenty-first century church. The section in Amos 5:21-27 is generally included in studies focusing on the prophetic critique of ritual and cult of the Hebrew Bible ${ }^{32}$ and the

31 Recently, M. Daniel Carroll R., 'Can the Prophets Shed Light on Our Worship Wars? How Amos Evaluates Religious Ritual', Stone-Campbell Journal 8 (2005): 21527, has discussed Amos' critique of ritual and cult in the larger context of modern worship wars and has provided an interesting angle to this issue. However, in the context of the present study we want to focus on the effects of Amos' critique of the cult in the larger context of society as a whole.

32 The prophetic critique of the cult of the HB has been the subject of important studies, as can be seen in the studies of Norman W. Porteous, 'Ritual and Righteousness: The Relation of Ethics to Religion in the Prophetic Literature', Interpretation 3 (1949): 400-14; J. Philip Hyatt, 'The Prophetic Criticism of Israelite Worship' in Interpreting the Prophetic Tradition. The Goldenson Lectures 1955-1966, ed. Harry M. Orlinsky (The Library of Biblical Studies; Cinncinati: Hebrew Union College Press; New York: KTAV, 1969): 201-24; Werner H. Schmidt, 'Prophetisches Zukunftswort und Priesterliche Weisung', Kairos 12 (1970): 289-308; Georg Fohrer, 'Kritik am Tempel, Kultus und Kultausübung in nachexilischer Zeit' in Archäologie und Altes Testament: Festschrift für Kurt Galling zum 8. Januar 1970, ed. Arnulf Kuschke and Ernst Kutsch (Tübingen: J. C. B. Mohr [Paul Siebeck], 1970): 101-16; Erich Zenger, 'Ritual and Criticism of Ritual in the Old Testament' in Liturgy and Human Passage, ed. David Power and Luis Maldonado (Concilium; New York: 
prophet belongs to a group of earlier prophets who had made this point before him (e.g. 1 Sam. 15:22; Hos. 6:6) and is followed by others whose message follows along similar lines (Isa. 1:15-18; Jer. 7). In NT times, Jesus himself seems to stand in this tradition, particularly in the context of the cleansing(s) of the temple (Matt. 21:12-22; Mark 11:1518; Luke 19:45-48; John 2:13-17). ${ }^{33}$

Amos 5:21-27 is part of a larger section that introduces for the first time in the book the Day of the Lord motif (Amos 5:18-27). ${ }^{34}$ Popular belief or the official royal theology of the day is directly refuted by the

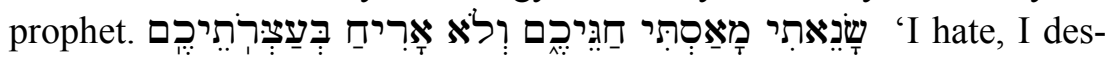
pise your festivals; and I take no delight in your solemn assemblies' (Amos 5:21). One of the key elements of this passage is the use of personal and possessive pronouns. In 5:21 YHWH expresses his active disgust with formal religious services practised by his people. In 5:22 this pattern is somewhat inverted, since it is Israel that actively offers burnt offerings and meal offerings, ${ }^{35}$ while YHWH only reacts at the end of the verse. ${ }^{36}$ So, what has caused this negative divine evaluation? Amos

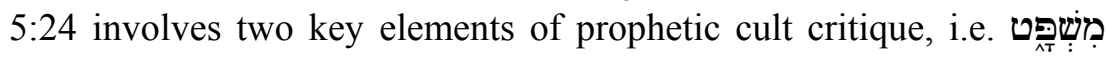
'justice', and צִדָָדז 'righteousness'. ${ }^{37}$ Because contemporary worship

Seabury Press/Crossroad, 1979): 39-49; Hans Jochen Boecker, 'Überlegungen zur Kultpolemik der vorexilischen Propheten' in Die Botschaft und die Boten: Festschrift für Hans Walter Wolff zum 70. Geburtstag, ed. Jörg Jeremias and Lothar Perlitt (Neukirchen-Vluyn: Neukirchener Verlag, 1981): 169-80; Lloyd R. Bailey, 'The Prophetic Critique of Israel's Cultic Order', Faith and Mission 6 (1989): 41-60; Mary C. Callaway, 'A Hammer That Breaks Rock in Pieces: Prophetic Critique in the Hebrew Bible' in Anti-Semitism and Early Christianity. Issues of Polemic and Faith, ed. Craig A. Evans and Donald A. Hagner (Minneapolis: Fortress, 1993): 21-38; Armin Lange, 'Gebotsobservanz statt Opferkult. Zur Kultpolemik in Jer. 7,1-8,3' in Gemeinde ohne Tempel/Community without Temple: Zur Substituierung und Transformation des Jerusalemer Tempels und seines Kults im Alten Testament, antiken Judentum und frühen Christentums, ed. Beate Ego et al. (WUNT 118; Tübingen: Mohr Siebeck, 1999): 19-35.

33 Craig A. Evans, 'From "House of Prayer" to "Cave of Robbers": Jesus' Prophetic Criticism of the Temple Establishment' in The Quest for Context and Meaning: Studies in Biblical Intertextuality in Honor of James A. Sanders, ed. Craig A. Evans and Shemaryahu Talmon (Biblical Interpretation Series 28; Leiden: Brill, 1997): 417-42.

34 Paul, Amos, 188, points out that the link between both sections is the common theme of contrast and the dramatic reversals. Smith, Amos, 176-83, has argued convincingly for the unity of the larger context, i.e. Amos 5:18-27.

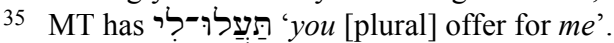

36 The second part of the verse involves different verbal forms, i.e. לא אַבָּיט... ליא אִ 'I do not accept... I do not even look.'

$37^{\circ}$ Amos has already introduced both terms (Amos 5:7) and will employ them again (Amos 6:12). The combination of both nouns occurs in forty-six verses of the Hebrew Bible, e.g. Gen. 18:19 [Abraham]; 2 Sam. 8:15 [David]; 1 Kgs 10:9 [Solomon], etc. By 
and cult go only skin deep, they lack conviction and real-life dimension and thus are only your interpretation of how it should be done. Ritual simply cannot substitute for the basic moral and ethical actions of humans. Justice and righteousness need to characterise the proper human-human relationship before ritual can truly impact the humandivine relationship. Ritual may rely on tradition but lacks divine approval as expressed by the constant contrasts contained in Amos' texts. ${ }^{38}$ It seems as if Amos criticises the automatisms that many people in Israel had associated with 'correct' ritual action. Furthermore, looking at the larger context, Amos unsparingly appraises erroneous theological statements, such as the one reflected in Amos 5:18, which considered the Day of the Lord concept as a useful tool to underline the divine election (and protection) of Israel - come what may.

This is a pertinent, but at the same time also uncomfortable message in the public square. Who would like to be told that religious forms (of any religion) cannot substitute for moral choices? Who would like to hear that the occasional generous offering for a good (or even religious) cause in the so-called Third World may not outweigh ignorance or just basic disinterest for economic, social, or moral issues affecting the billions of people living in these countries? According to Amos 'justice' and 'righteousness' are key ingredients of true worship of YHWH and cannot be substituted. One wonders how Christians (including Evangelicals), living in North America or Western Europe, feel and speak publicly about these issues. While 'justice' and 'righteousness' appear to be key terms in non-Christian talking about social issues, it often seems as if conservative Christianity has filed them under 'Liberation theology' and marked them as 'already taken, and thus not really relevant for our talking about life on planet earth.' 39

far the highest density of this combination can be found in prophetic writings, including Isaiah (10×), Jeremiah (6×), Ezekiel (8×), Amos $(3 \times)$ and Micah $(1 \times)$.

38 Interestingly, in Isa. 56:7 YHWH pronounces that the 'sons of the foreigner' will be led to my holy mountain and shall be made joyful in my house of prayer. Their burnt offerings and sacrifices will be accepted on $m y$ altar, for $m y$ house shall be called a house of prayer for all peoples (based upon NJB). A clear interaction exists between the pronominal suffixes utilised in the Hebrew text.

39 A pertinent review of the importance and relevance of Liberation Theology can be found in Miguel Ángel Núñez, 'Relevancia y pertinencia actual de la Teología de la Liberación', DavarLogos 4 (2005): 49-63. Núñez highlights particularly the tremendous changes in general hermeneutics and the effect of 'liberationist thinking' in other adjacent disciplines. He concludes: 'Se necesita salir de la intransigencia frente a la TL [= Teología de la Liberación] y elaborar propuestas teológicas que no recurran a los medios de análisis que utilizó la TL, pero, que sean capaces de dar respuestas no 
Another important issue that is relevant for our present discussion has to do with the interaction of theology and practical living. Often, modern talking about God is exactly this, i.e. 'talking' and does not involve solid theological thinking. ${ }^{40}$ Profound thinking and careful reasoning is sacrificed for catchy soundbites or easily repeated slogans. When Amos talks about faulty theological concepts involving the Day of the Lord and the function of ritual and cultic expressions in worship, he definitely opts for the more difficult route and challenges us to do the same.

\section{Amos 7-9: Five Visions of Judgement and the Public Square}

As much as judgement was part of ancient Israel's literal public square, i.e. the court convening in the gate area of the city, ${ }^{41}$ the message of YHWH's judgement over Israel is an integral part of the prophet's ministry in the public square. Judgement messages appear to be the most common aspect of the OT prophet's job description, and its transmission and reception uncountable times endangered the messenger's own life. ${ }^{42}$ The five judgement visions, as recorded in Amos 7:1-3, 4-6, 7-9; 8:1-3; and 9:1-4, demonstrate how judgement is related through different images to different people. ${ }^{43}$ It has been repeatedly observed that there is a noticeable progression in both the object and content of judgement as presented in these oracles. Vision

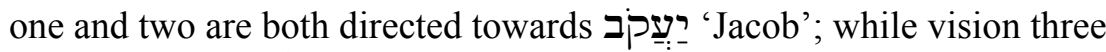

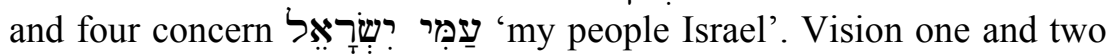

evasivas y bíblicas a problemas reales que enfrentan las personas hoy. En otras palabras, es fundamental pasar del ataque al análisis profundo de las problemáticas que dieron origen a la TL, pero desde una perspectiva que considere la autoridad de la Biblia y las metas evangelizadoras que ésta propone' (Miguel Ángel Núñez, 'Relevancia', 63).

40 Ekkehardt Müller, 'Theological Thinking in the Adventist Church', DavarLogos 1 (2002): 125-47, has discussed important issues in theological thinking (and the underlying question about the interaction between praxis and theory) in the context of the Seventh-day Adventist Church. It is our impression that most observations would also be applicable to other Christian denominations.

41 See above footnote 2 .

42 Cf. Amos 7:10-17.

43 While judgement is certainly also present in the first part of the book which records the words of Amos (Amos 1:3-6:14), we will concentrate on the second major division of the book, i.e. the visions of Amos (Amos 7:1-9:15). Cf. Smith and Page, Amos, Obadiah, Jonah, 126. 
are cancelled on account of the prophet's intercession, because although Israel during the reign of Jeroboam II was politically strong, it remained spiritually insignificant before YHWH. ${ }^{44}$ Vision three and four seem to progress towards an unavoidable verdict. However, the judgement is still a future event associated with the 'day of the Lord' ${ }^{45}$ Most commentators have observed that these four visions form two pairs with the fifth vision describing the climax in the progressive judgement proclamation. ${ }^{46}$ Vision five has the most inclusive addressee (כָּד 'all of them') and the execution of the judgement is described in

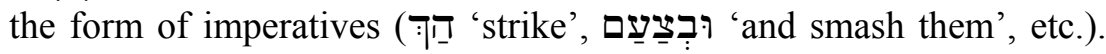
While these five progressively more intense visions are compressed in a breath-taking staccato of sixteen verses with two interludes after the third and fourth vision (Amos 7:10-17; 8:4-14), their original settings could probably be connected with a growing spiritual apostasy over a longer period of time. The prophet is reacting to this, sketching the progression from averted to proclaimed and executed judgement. This is a repetitive pattern throughout the Bible at those intersections when YHWH intervenes actively in history through judgement. ${ }^{47}$ Especially

44 Interestingly, the reason given by Amos is that Jacob is so pop 'small', while in real-life regional politics it was far from being neither insignificant nor weak during the reign of Jeroboam II, the historically golden era of the northern kingdom. Reimer picks up on that apparent historical inconsistency and furthermore sees agricultural metaphors being used in the first two visions on the basis of which he proposes that Jacob is referring to the underprivileged social segment of farmers in Israel who were suffering under social injustice. He then comes to the conclusion that this population group was spared from judgement and that God judges different people in different ways. 'In Am 7,4-6 steht „Jakob“ für den einzelnen israelitischen Kleinbauern, dessen Produktionsmittel, nämlich der ihm und seiner Familie zustehende Ackeranteil, durch völlige Ausdörrung gefährdet ist.' See Haroldo Reimer, Richtet auf das Recht! Studien zur Botschaft des Amos (Stuttgarter Bibelstudien 149; Stuttgart: Verlag Katholisches Bibelwerk, 1992): 172. While Reimer's conclusion is theologically correct, unfortunately, there is no textual evidence to identify Jacob with a socially subjugated group of Northern Israelite farmers and the reading appears more consistent with the South American background of the author.

45 See Rolf Rendtorff, "Alas for the Day! The "Day of the Lord" in the Book of the Twelve' in God in the Fray: A Tribute to Walter Brueggemann, ed. Timothy K. Beal and Tod Linafelt (Minneapolis, MN: Fortress, 1998): 186-97.

46 For example, Reimer, Richtet auf das Recht!, 160-61; Walter Beyerlin, Bleilot, Brecheisen oder was sonst? Revision einer Amos-Vision (Orbis Biblicus et Orientalis 81; Fribourg and Göttingen: University Press and Vandenhoeck \& Ruprecht, 1988): 49; H. G. M. Williamson, 'A Redaction-Critical Study of Amos 7' in 'The Place Is Too Small for Us': The Israelite Prophets in Recent Scholarship, ed. R. P. Gordon (Sources for Biblical and Theological Study 5; Winona Lake, IN: Eisenbrauns, 1995): 453-54.

47 "“The land cannot bear all his words" implies a considerable time and range for the prophet's preaching ministry.' Smith and Page, Amos, Obadiah, Jonah, 137. 
the third-person biographical narrative of Amos 7:10-17 has attracted considerable attention. ${ }^{48}$ With regard to our discussion of Amos in the public square, it demonstrates that the public square often rejects the prophet's testimony. The two most important institutions of public life, monarchy and priesthood, ${ }^{49}$ give a negative evaluation of both the prophet and his message. According to Amaziah, the priest of Bethel, Amos may be a דזֶז 'seer' but definitely not a נִביָ 'prophet' besides that, a foreigner who should rather try to earn his living back home in Judah. The inserted narrative comes after the first vision that has a definite character with regard to its outcome unlike the preceding ones, and its position is far from being arbitrary or a later redactional addition as has been argued. Rather it shows how a consistent call to reform can evoke a likewise consistent resistance in the audience and even in the institutions which originally were commissioned by God to fulfill the task of spiritual leadership in Israel so that an unqualified foreigner finds himself filling this role. The translation of אִָּ as 'plumb line' in Amos 7:7-8 has been criticised repeatedly. ${ }^{51}$ However, according to Williamson there is no evidence against translating it this way and this particular reading would be the one the context supports most adequately. ${ }^{52}$ The plumb-line would then refer to the prophet himself which would also explain the insertion of the biographical narrative right afterwards. ${ }^{53}$ The building imagery is indicative of the prophet's public square role and the possible resistance to it.

48 For a summary of relevant position, cf. Williamson, 'A Redaction-Critical Study of Amos 7', 453-58.

49 'Then Amaziah the priest of Bethel sent a message to Jeroboam king of Israel: "Amos is raising a conspiracy against you in the very heart of Israel. The land cannot bear all his words"' (Amos 7:11).

50 Although these terms are mostly used interchangeably throughout the OT, a case could be made for a derogatory use of the term which also is applied to Balaam, a diviner that is up for hire. Cf. Smith and Page, Amos, Obadiah, Jonah, 137.

51 Cf. NIB 7:406-07. For a summary of the different translation suggestions and a respective critique of these positions, see Williamson, 'A Redaction-Critical Study of Amos 7', 462-65.

52 Williamson, 'A Redaction-Critical Study of Amos 7', 467.

53 'In this paper, I have argued (i) that previous explanations for the positioning of Amos 7:9-17 are unsatisfactory; (ii) that contextual considerations favour the interpretation of 'anāk as 'plumb-line' and that philological arguments do not rule this out; and (iii) that, in line with their view of the role of prophets as known from elsewhere, the Deuteronomists, or at any rate a writer very much in tune with their thought, inserted this paragraph to interpret God's plumb-line as Amos himself, whose rejection then led to the final announcement of the end of Israel.' Williamson, 'A Redaction-Critical Study of Amos 7', 476. 
Nonetheless, the fourth vision of judgement follows suit, centred on the 'Day of the Lord' motif which is one of the most prevalent biblical judgement metaphors found in the Hebrew Bible. ${ }^{54}$ The theme of proclaimed and executed judgement can be recognised from Genesis to Revelation with its proclamation predominantly occurring in the public square. ${ }^{55}$ It begins with God looking for humanity after the fall (Gen. 3:9) and pronouncing judgement, but setting it in a redemptive context of grace (Gen. 3:14). The same message echoes throughout the 120 years of Noah's untiring efforts to proclaim imminent destruction before the rain began to fall, inviting people to join him and his family on a solitary cruise into the future. ${ }^{56}$ Genesis 19 describes the intricate interplay of judgement and salvation, concluding with the grace-based rescue of Lot from the burning city. The conquest of Canaan occurs after a period of grace of more than 400 years (Gen. 15:16) in which the inhabitants of Canaan interact repeatedly with God's people (e.g. Gen. 14). ${ }^{57}$ There are 'Days of the Lord' for various other nations throughout the Hebrew Bible: Assyria after an almost 200 year interval between Jonah and Nahum; ${ }^{58}$ Babylon forewarned by Isaiah (Isa. 13:122); Medo-Persia (Dan. 8:20); Greece (Dan. 8:21); Rome (Dan. 8:9, 23-25), etc., all of them serving as an object lesson for God's own people. For Israel is also subject to the divine imperative of salvation by means of judgement and the focus of prophetic literature in the

54 Rolf Rendtorff, 'Alas for the Day!' in God in the Fray, 186-97. Cf. also F. Charles Fensham, 'A Possible Origin of the Concept of the Day of the Lord', in Proceedings of the Ninth Meeting of 'Die Ou-Testamentiese Werksgemeenskap in Suid-Africa' (Stellenbosch, 1966): 90-97.

55 The following is based on Gerhard F. Hasel, 'Divine Judgment' in Handbook of Seventh-day Adventist Theology, ed. Raoul Dederen (Commentary Reference Series 12; Hagerstown, MD: Review and Herald Publishing Association, 2000): 815-56.

56 Cf. H. S. Benjamins, 'Noah, the Ark, and the Flood in Early Christian Theology: The Ship of the Church in the Making' in Interpretations of the Flood, ed. Florentino García Martínez and Gerard P. Luttikhuizen (Themes in Biblical Narrative 1; Leiden: Brill, 1998): 134-49.

57 'It is significant that Abraham is described as having so well integrated into the Southern Canaan communities by ways of political treaties (v. 13) that the Canaanites without hesitation follow him on a wild goose-chase that is motivated by his family obligations. [...] the Canaanites had recognized "Abraham as a mediator of blessing".' Martin G. Klingbeil, 'Exclusivism or Inclusivism: The Concept of Citizenship in the Pentateuch and Its Metaphorical Usage in Ephesians', Journal of Asia Adventist Seminary 9.2 (2006), forthcoming.

58 Beate Ego, 'The Repentance of Nineveh in the Story of Jonah and Nahum's Prophecy of the City's Destruction: Aggadic Solutions for an Exegetical Problem in the Book of the Twelve', in Society of Biblical Literature 2000 Seminar Papers (SBL Seminar Paper Series 39; Atlanta, GA: Society of Biblical Literature, 2000): 243-53. 
Hebrew Bible is to avert judgement through repentance or to finally announce the execution of judgement as in the Assyrian and Babylonian exiles. All these judgements are then projected forward along a typological line into an eschatological future by a number of prophets of Hebrew Bible (Joel 1:15; Isa. 2:6-22; 24-27; Dan. 12:1-3), but are also echoed in the NT (John 5:29; Matt 13:40, 49) up to the inauguration of the final judgement procedure that is proclaimed in Revelation 14:6-12. 'Divine judgement is called for at the various junctures of human history. Repeatedly the grace of God is at work with repeated invitations to repent and return to a loving and benevolent God whose purpose it is to save any who wish to be saved.' 59 These invitations are uttered, sometimes under painful circumstances, by the prophets in the public square.

\section{Amos 9:11-15: Leaving the Public Square with a Message of Hope}

The apparent break between the concluding verses of Amos with his preceding messages has been expressed poignantly by Wellhausen: 'Rosen und Lavendel statt Blut und Eisen'. ${ }^{60}$ This observation has caused numerous commentators to doubt the authenticity of the passage and presuppose different authorship for the epilogue. ${ }^{61}$ The argumentation usually invokes linguistic and theological data, but can be reduced to a dichotomist view between judgement and salvation, stating the impossibility of both appearing within close proximity. ${ }^{62}$

\footnotetext{
59 Hasel, 'Divine Judgment' in Handbook of Seventh-day Adventist Theology, 821.

60 Julius Wellhausen, Die kleinen Propheten übersetzt und erklärt (4th edition; Berlin: de Gruyter, 1963): 96.

61 'There is common agreement among most commentators that the last verses are from the hand of an exilic or postexilic theologian-redactor who, from his own Judean point of view, bore tidings of consolation and salvation to his people' (Paul, Amos, 288).

62 A summary of the various arguments against authenticity is presented in W. A. G. Nel, 'Amos 9:11-15-An Unconditional Prophecy of Salvation during the Period of the Exile', Old Testament Essays 2 (1984): 90-93. Unfortunately, the author does not look critically at these arguments and fails to present the counter-arguments. He then comes to the following somewhat superficial conclusion: 'The entire preceding discussion convinces me that Amos 9:11-15 could not have been the work of Amos himself' (93). Again the force of the argument lies on the presupposed incongruence between a judgement and salvation theology.
} 
However, a closer look reveals numerous linguistic and theological affinities between the epilogue and the rest of the book. If one looks at the delimitation markers found in the MT, there is a petûhah after v. 12 , connecting it thus more to vv. 7-12 and separating it from vv. 13-15 so that the final three verses really become the epilogue of the epilogue. The first unit (Amos 9:7-12) already sets the stage for the transition from judgement to salvation via the concept of the shaking of Israel which will only sieve out the sinners in Israel. ${ }^{63}$ The introduction to the first restoration promise through the prophetic formula הַהוּץ 'in that day' has been used throughout the book (Amos 2:16; 8:3, 9,13 ) and serves as an answer to the rhetorical questions which have opened the section in v. 7. While Israel in its Gottesferne was not any different from the other nations, YHWH will now restore a purified Israel, which can only differentiate itself from the other nations if it has undergone the process of cleansing as outlined in the preceding verses. The reappearance of the nations-motif creates an inclusio for the whole book: '[...] the recovery of the Davidic empire complements the condemnation of the nation states of the Davidic empire (Amos 1:3-

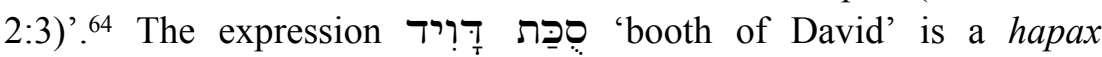
legomenon and has been interpreted in different ways, possibly referring to a building from David's time. ${ }^{65}$ It is used to epitomise the bright and paradigmatic aspect of David's reign which serves as a blueprint for restoration. This would be in line with the following second promise of restoration which is configured around an agricultural and building metaphor.

The perspective of the first promise of restoration is enlarged

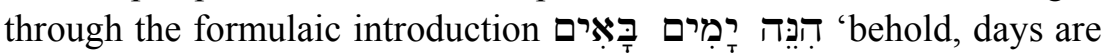

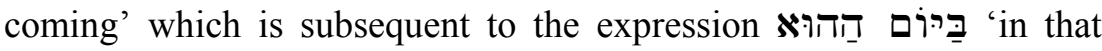
day' which introduced the first promise. After the judgement restoration is now extended to the land, its infrastructure, and its

63 'Surely the eyes of the Sovereign LORD are on the sinful kingdom. I will destroy it from the face of the earth - yet I will not totally destroy the house of Jacob', declares the LORD. 'For I will give the command, and I will shake the house of Israel among all the nations as grain is shaken in a sieve, and not a pebble will reach the ground. All the sinners among my people will die by the sword, all those who say, "Disaster will not overtake or meet us"' (Amos 9:8-10).

64 Cross apud Paul, Amos, 202.

65 It could refer to the tabernacle that David erected when he brought the ark to Jerusalem (2 Sam. 6) or to a temporary pavilion that was erected during David's military campaign. Cf. Andersen and Freedman, Amos, 914-15. 
people; the agricultural metaphor in Amos 9:13-14 encompasses the whole sphere of farming activity throughout the year: plowing, reaping, treading, and sowing will overlap because fertility is so over-abundant that one harvest will chase the next one. ${ }^{66}$ This over-abundance is continued in the second half of the verse and its close conceptual proximity to Joel $3: 18$ [ET 4:18] should be noted: 'In that day the mountains will drip new wine, and the hills will flow with milk; all the ravines of Judah will run with water. A fountain will flow out of the LORD's house and will water the valley of acacias.' Both in Amos and Joel, the statements occur towards the end of the books and Joel displays the same interplay between judgement and salvation which would further point to the authenticity of the epilogue.

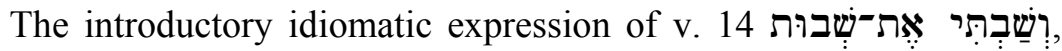
literally translated with 'I shall turn a turning', has been related to preexilic times both extra- and intra-biblically, ${ }^{67}$ and launches a reversal from wasted ruins to reconstructed cities, planted vineyards, and cultivated gardens. Similar promises of blessings are found throughout the prophetic literature. ${ }^{68}$ The final verse of the book abstracts the future blessings and transfers them to the people who are pictured as a plant firmly and forever rooted in the land.

A final observation may be in order regarding the usage of these two metaphors, i.e. the agricultural and building metaphor. Besides the fact that they reflect very well the profession of Amos the sheep breeder and land cultivator, they conclude the prophetic book with an imagery that is deeply rooted in one of the most prominent theological traditions of the prophetic literature of the Hebrew Bible, i.e. creation. Both agricultural imagery and building imagery can be related to the theme of creation, ${ }^{69}$ suggesting a progression from creation via de-creation to re-creation.

66 An interesting parallel can be derived from a Mesopotamian 'prophetic text' as quoted by Paul: 'The winter grass || vegetation will last until the summer grass || vegetation; the summer vegetation will last until the winter vegetation.' Compare Paul, Amos, 293.

67 A number of commentators identify it as post-exilic and Deuteronomistic. However, compare for example the eighth-century Aramaic inscription from Sefire (III 24-25) and Jer. 30:3 where identical expressions occur. See also Andersen and Freedman, Amos, 924.

68 For example: Isa. 65:21; Jer. 29:5, 28; 33:10; Ezek. 28:26; etc.

69 See, e.g. Ezek. 47:12; Zech. 10:1. While YHWH is the builder of Jerusalem after the Babylonian exile (Jer. 24:6), he is also the builder of Eve in Gen. 2:22. In both instances the lexical creation marker בנה 'build' is used. For a more comprehensive 
Amos leaves the public square with a strong theological statement of hope and promise of restoration; this is probably a good point and possibly the focal point where the prophetic message needs to end. $\mathrm{He}$ is certainly not alone in this grand exit. Mention can be made of other prophets such as Isaiah, Joel, and Micah, whose exit is similarly designed. While the prophetic voice cannot bypass the message of judgement, salvation is the other side of the same coin and judgement becomes a prerequisite to salvation.

\section{Instead of a Conclusion}

Instead of providing a mere summary and a perspective for further research, we would like to challenge the contemporary Christian and the church as a whole. We stand here in the tradition of Amos, the sheep-breeder turned prophet, who entered the public square of eighthcentury B.C.E. Israel at a time when things were apparently going well and whose voice was not only heard by the leadership and the people of ancient Israel, but which still challenges the Christian church in the twenty-first century which also needs to make its voice heard in our public square(s).

Contemporary public squares are overcrowded by many different voices and the filters that are applied to this multitude of voices are often tweaked in such a way as to exclude any voice that does not conform to the trends of popular opinion. The challenge is twofold: first, the Christian's voice must be brought to the public square and, second, the message must be recognisable amidst the dim of other voices. Amos provides a short checklist of elements that may prove helpful in bringing the Christian's voice to the public square and letting it be heard.

(1) The message must be international and not bound by national borders and realities, tribalism or clan mentality, as we form part of an international community that might be identified but should not be limited by ethnic, cultural or tradition-determined borders. Globalisation appears to go hand in hand with an increasing nationalism as

discussion of the issue see Martin G. Klingbeil, 'Creation in the Prophetic Literature of the Old Testament' (Biblical Research Institute; General Conference of SDA; forthcoming). See also Stefan Paas, Creation \& Judgement: Creation Texts in Some Eighth Century Prophets (Oudtestamentische Studiën 47; Leiden: Brill, 2003). 
people try to preserve their own identity. Amos moves across borders, politically, professionally, and geographically, and reaches out to a community which has become estranged from, if not hostile towards, his own community. His message to the nations is a message of social responsibility and universal justice which includes self-critique. It is not an 'us right here' over against a 'them out there', but a plea for the defenceless, downtrodden, and degraded right here and out there.

(2) In order for our message to reach and be relevant in the public square, we will have to look beyond form and tradition toward content. Religiosity at the expense of practical and ethical daily living is not sufficient to pass divine scrutiny. Should an attempt be made to avoid theological reasoning and content by substituting a skin-deep level of spiritual emotion, a shift towards the darker and not so glorious aspects of the Day of the Lord will occur. However, when justice and righteousness begin to characterise our interpersonal relationships, then ritual, cult and worship can take their appropriate place in the humandivine relationship.

(3) It is difficult, though maybe to some extent popular, to ignore what appears to be the central message of the preacher in the public square. We have developed a blind spot for messages focusing on the theme of judgement. In view of the magnitude and projected impact these messages have, what can be more relevant in the public square? The eternal message of judgement (Rev. 14) may not guarantee a top spot on the popularity chart, but may amplify and personalise God's eternal searching question: 'Adam where are you? I desperately need to find and save you.'

(4) The reverse side of the coin of judgement is salvation, and Amos leaves the public square with a glorious message of hope and restoration. Our mission must be hope-driven and the public square needs to ring with that hope. Restoration is not exclusively futureoriented but holistic in that restoration begins here and now with the rebuilding of the land and its people, followed by fruit and more fruit, abundant fruit. 